DOI: $10.2478 / \mathrm{v} 10025-010-0035-4$

JOURNAL OF WATER

AND LAND DEVELOPMENT

J. Water Land Dev. No. 13a, 2009: 283-297

\title{
Precipitation chemistry in a forested study area of the Chojnów Forest District in the years 2004-2007
}

\author{
Anna KOWALSKA, Magdalena JANEK
}

Forest Research Institute, Forest Site Science Department, Sękocin Stary, ul. Braci Leśnej 3, 05-090

Raszyn; e-mail: a.kowalska@ibles.waw.pl,m.janek@ibles.waw.pl

\begin{abstract}
Analyses of precipitation in the forest environment were conducted in the years 20042007 in a premanent observation plot established in a pine forest stand growing in a mixed fresh coniferous forest habitat in the Chojnów Forest District. The amount and chemistry of atmospheric precipitation in the open field and under canopies were analysed. Electrical conductivity, $\mathrm{pH}$, and concentrations of $\mathrm{Ca}, \mathrm{Mg}, \mathrm{Cl}, \mathrm{NO}_{3}, \mathrm{SO}_{4}, \mathrm{Na}, \mathrm{K}, \mathrm{Fe}, \mathrm{Mn}, \mathrm{Al}, \mathrm{NH}_{4}, \mathrm{PO}_{4}, \mathrm{Zn}, \mathrm{Cd}, \mathrm{Cu}$ and $\mathrm{Pb}$ were determined in collected samples.

Mean annual precipitation in the open field for the years 2004-2007 was $443 \mathrm{~mm}$. Mean $\mathrm{pH}$ (volume weighted) in this period equalled 4.8 and electrical conductivity $-47 \mu \mathrm{S} \cdot \mathrm{cm}^{-1}$. Mean precipitation under trees crowns $\left(411 \mathrm{~mm} \cdot \mathrm{y}^{-1}\right)$ was lower than bulk precipitation. Throughfall was characterised by lower $\mathrm{pH}$ (mean 4.2$)$ and higher conductivity $\left(62 \mu \mathrm{S} \cdot \mathrm{cm}^{-1}\right)$. Throughfall was enriched, mostly in hydrogen ions, $\mathrm{Mn}, \mathrm{K}, \mathrm{Al}, \mathrm{Mg}$, and $\mathrm{Ca}$ ions with respective enrichment factors of: 67, 20, 9, 5, 4 and 2 .
\end{abstract}

Key words: bulk precipitation, enrichment factors, precipitation, throughfall

\section{INTRODUCTION}

Flora, especially tree stands for their large size, in a given area affect the amount and quality of atmospheric precipitation reaching the soil. The role of tree stand in the modification of rainfall quality is associated with both the uptake of various elements by plants from these waters and the enrichment of rainfall in some elements (UlRich, 1983; HANSEN, 1994; KVAALEN et al., 2002; SZPIKOWSKI et al., 2006). The plant-precipitation interactions pertain to above-ground plant parts and in a tree stand they take place mainly in tree crowns. These processes are reflected by different chemical composition of bulk precipitation, throughfall and stemflow. Concentrations of elements in the water reaching substratum depend on various factors like: atmospheric pollution, amount and type of precipitation, and species-specific interception by tree surfaces (Ocena..., 1996; KRZYSZTOFIAK, 
2006). An increase in the concentration of ions is a result of evaporation, dust particles washout and leaching of components from plant cells which also increase electrical conductivity of solutions. Rainfall contacting plants is enriched due to washing out dry deposition from plants' surfaces (e.g. sulphur) and release of other components from plant cells (e.g. potassium). The uptake of ions by plants concerns mainly plant nutrients, mostly - nitrogen.

The aim of this paper was to identify the effect of pine tree stand on rainfall volume and chemistry. Presented results summarize four-year long study on the quantity and quality of bulk precipitation in the open field and throughfall.

\section{STUDY SITE AND METHODS}

Study area was located in the Chojnów Forest District (division 166), ca. 20 $\mathrm{km}$ from Warsaw $\left(52^{\circ} 01^{\prime} 00^{\prime \prime} \mathrm{N}, 21^{\circ} 06^{\prime} 00^{\prime \prime} \mathrm{E}\right), 108 \mathrm{~m}$ above sea level, in a lowland area without any inclination. According to the Natural - Forest Regionalisation, the Forest District area is located in the Mazovian-Podlasie region, of the WarsawKutno lowland district, mesoregion of the Kutno-Błonie lowland. A complex of Chojnów forests is part of the Chojnów Landscape Park, important for its climate, natural values and landscape features, and forms buffer zone for Warsaw agglomeration from the south.

Study plot is a rectangle $30 \mathrm{~m} \times 50 \mathrm{~m}$. It is overgrown by a single-storey pine stand typical for this region of Poland. The main species is the Scots pine (Pinus sylvestris L.) 63 years old in 2003 (the year of commencing the study) of the second class of site index. Accompanying species in the stand are: the sessile oak (Quercus petraea (Mattuschka) Liebl.) and silver birch (Betula pendula Roth). The oak grows also, in large numbers, in the understorey. The habitat was classified as fresh mixed coniferous forest, with Querco roboris-Pinetum typicum community.

Mean annual precipitation in the study period was $523 \mathrm{~mm}$ and mean annual air temperature $-8.9^{\circ} \mathrm{C}$ acc. to data of the Institute of Meteorology and Water Management (IMGW) from the nearest meteorological station - Warsaw Okęcie. Maximum temperatures were noted in the period between June and August when mean monthly values ranged from 15.8 to $23.5^{\circ} \mathrm{C}$. The coldest months were December, January, and February with average temperatures between -8.3 and $-3.9^{\circ} \mathrm{C}$.

The study plot was established in 2003, and regular surveys started from January 2004. The range of studies falls within the scope of European forest monitoring system carried out at the Forest Research Institute (Manual..., http:). Analyses of water quantity and quality were performed biweekly from January 2004 to the middle of 2005 and at month intervals later on. The analyses involved bulk precipitation in the open field and throughfall. Initially stemflow was also analysed but due to the character of tree stand dominated by pine trees and resulting minor share 
of stemflow in ion deposition these analyses were abandoned in the middle of the year 2005.

Bulk precipitation was collected at a distance of ca. $2 \mathrm{~km}$ from the forest stand. Samples in the summer time were collected in parallel to 2 polyethylene collectors with the capacity of $3 \mathrm{dm}^{3}$ equipped with a funnel with the surface area of $177 \mathrm{~cm}^{2}$. A sieve in the funnel was used to prevent from collecting flora, insects, and other organic particles. The content of collectors was protected with a polystyrene enclosure from direct solar radiation. In the winter time, with prevailing snow falls, samples were collected in open containers with a surface of $491 \mathrm{~cm}^{2}$ and capacity of $10 \mathrm{dm}^{3}$.

Troughfall was collected into 15 collectors, evenly spaced underneath tree canopy at a height of ca. $140 \mathrm{~cm}$ along one of the plot's diagonal. In the summer time the collecting surface of a single collector was $113 \mathrm{~cm}^{2}$ and capacity $-1 \mathrm{dm}^{3}$. The content of a container was protected from sun exposure with aluminum foil. During winter the equipment was replaced by open containers with a diameter of $22 \mathrm{~cm}$ and surface area of $380 \mathrm{~cm}^{2}$ lined with PE foil. After sampling all parts of devices were washed and rinsed with deionised water. No preservative agent was used to protect the samples against changes of chemical composition during sampling.

Immediately after collecting water samples were transported to the laboratory where, on the collecting day, their volume was measured by weighing, electrical conductivity - by the conductometric method, and $\mathrm{pH}$ - by the potentiometric method. Precipitation was calculated from the volume of collected sample and the containers' diameter. The remaining part of the sample was filtered through membrane filters with pore size of $0.45 \mu \mathrm{m}$ and then divided into two sub-samples: one stabilized by nitric acid addition (0.5/100 parts of water). $\mathrm{Ca}, \mathrm{Mg}, \mathrm{Na}, \mathrm{K}, \mathrm{Fe}, \mathrm{Mn}$, $\mathrm{Al}, \mathrm{Zn}, \mathrm{Cd}, \mathrm{Cu}$, and $\mathrm{Pb}$ were determined by the atomic emission spectrometry method ICP-OES. The second subsample was analysed for the content of chloride, nitrate $(\mathrm{V})$, sulphate $(\mathrm{VI})$, and phosphate $(\mathrm{V})$ anions, and ammonium ions by the ion chromatography method. Chromatographic analyses were performed within 1-2 days after sample collecting or samples were frozen in a temperature below $20^{\circ} \mathrm{C}$ for a period of maximum 1 month. The 1 month sample storage without freezing was allowed before metal analysis.

Results of the analyses were checked using ionic balance, by comparing measured and calculated conductivity, and by evaluating sodium to chloride molar ratio. Unsatisfactory test was a basis for sample reanalysis. The results were accepted if the reanalysis did not bring major changes.

Statistical calculations were made with STATISTICA software. 


\section{RESULTS}

\section{BULK PRECIPITATION}

Annual bulk precipitation in the years 2004-2007 ranged from $401 \mathrm{~mm}$ in 2007 to $483 \mathrm{~mm}$ in 2006 with a mean for the study period of $443 \mathrm{~mm}$ (Tab. 1). Surprisingly high monthly precipitation of $149 \mathrm{~mm}$ was recorded in August 2006. However, no regularities were observed in the distribution of monthly precipitation in consecutive years.

The $\mathrm{pH}$ of precipitation averaged over monthly periods varied between 4.1 and 7.2 and indicated clear seasonal changes from the maximum in summer months to minimum in winter months (Fig. 1). Mean $\mathrm{pH}$ (volume weighted) in the study period was 4.8 , whereas mean electrical conductivity was $47 \mu \mathrm{S} \cdot \mathrm{cm}^{-1}$ with monthly variations between 11 and $242 \mu \mathrm{S} \cdot \mathrm{cm}^{-1}$.

Concentration of ions in precipitation did not show large variations among consecutive years. From among alkaline metals calcium showed highest weighted mean concentration followed by sodium, potassium, and magnesium, with respective concentrations of: $1.31,0.47,0.43$, and $0.14 \mathrm{mg} \cdot \mathrm{dm}^{-3}$. Among acidifying ions, the highest concentration was recorded for sulphate-sulphur $\left(2.20 \mathrm{mg} \cdot \mathrm{dm}^{-3}\right)$, then ammonium-nitrogen $-2.09 \mathrm{mg} \cdot \mathrm{dm}^{-3}$, chlorides $-1.48 \mathrm{mg} \cdot \mathrm{dm}^{-3}$, and nitratenitrogen $-1.01 \mathrm{mg} \cdot \mathrm{dm}^{-3}$ (Tab. 1).

Concentrations of heavy metals in precipitation were often very close to the detection limit of the analytical method. Mean concentrations in bulk precipitation were: $1.176 \mathrm{mg} \mathrm{Zn} \cdot \mathrm{dm}^{-3}, 0.017 \mathrm{mg} \mathrm{Cu} \cdot \mathrm{dm}^{-3}, 0.012 \mathrm{mg} \mathrm{Pb} \cdot \mathrm{dm}^{-3}$, and $0.001 \mathrm{mg}$ $\mathrm{Cd} \cdot \mathrm{dm}^{-3}$.

\section{THROUGHFALL}

Annual precipitation under canopies ranged from $384 \mathrm{~mm}$ to $430 \mathrm{~mm}$ with the mean of $411 \mathrm{~mm}$, being smaller than that in the open field (Tab. 1). As in the bulk precipitation, the highest $\mathrm{pH}$ was found in water samples collected in summer months, and the lowest in winter months (Fig. 1). Monthly mean $\mathrm{pH}$ values varied between 3.8 and 5.4. At the same time, the mean annual $\mathrm{pH}$ value (4.2) was substantially lower than that in the open field.

Troughfall was characterised by a higher conductivity than bulk precipitation. Mean conductivity in the study period was $62 \mu \mathrm{S} \cdot \mathrm{cm}^{-1}$, and weighted monthly averages varied between 20 and $161 \mu \mathrm{S} \cdot \mathrm{cm}^{-1}$.

Potassium and calcium ions dominated in the sum of alkaline ions in the throughfall (2.55 and $1.96 \mathrm{mg} \cdot \mathrm{dm}^{-3}$, respectively). Sodium and magnesium ions showed lower weighted mean annual concentrations of 0.61 and $0.57 \mathrm{mg} \cdot \mathrm{dm}^{-3}$, respectively. Acidifying ions were dominated by sulphate-sulphur $\left(2.34 \mathrm{mg} \cdot \mathrm{dm}^{-3}\right)$ 


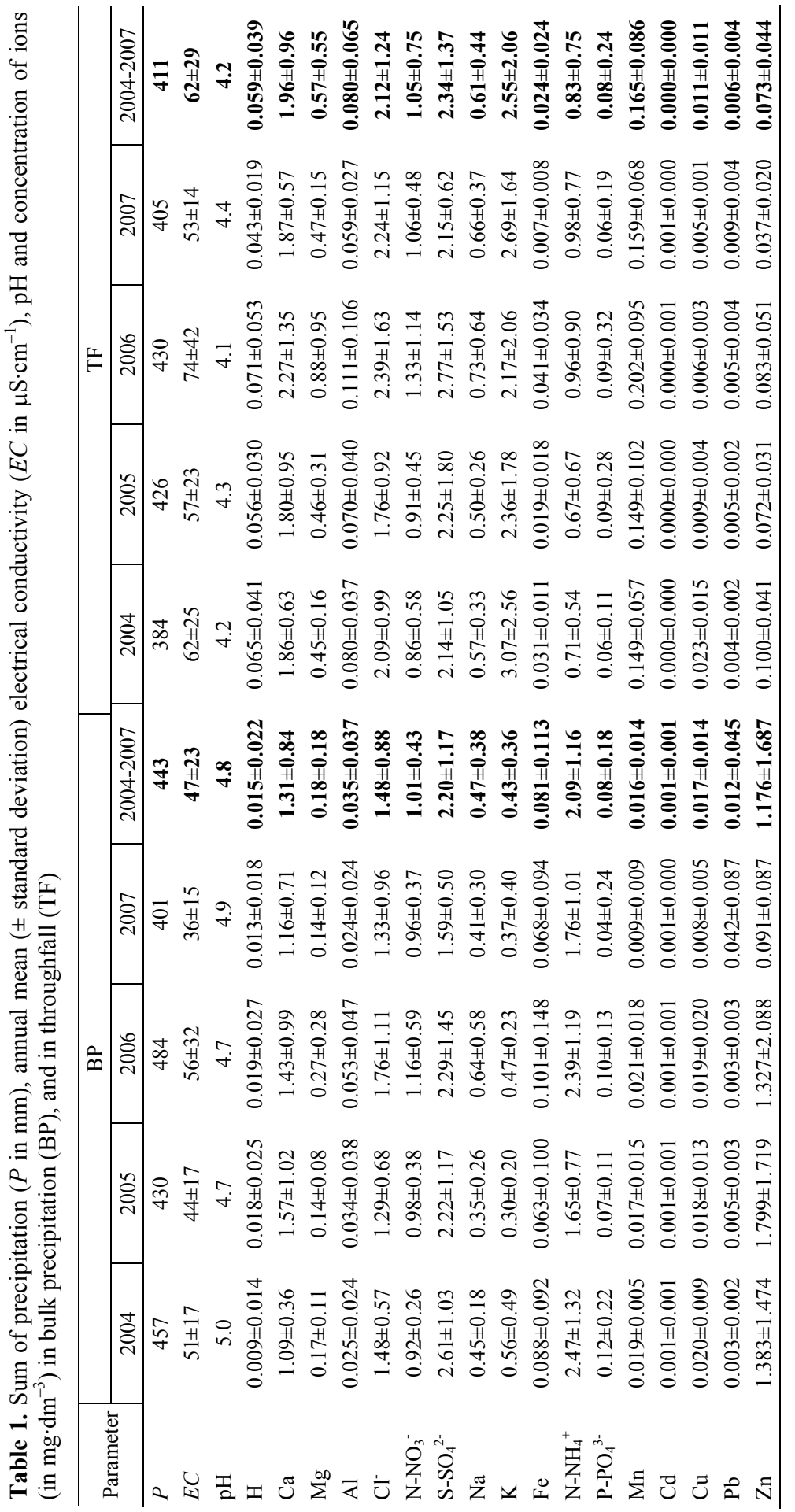




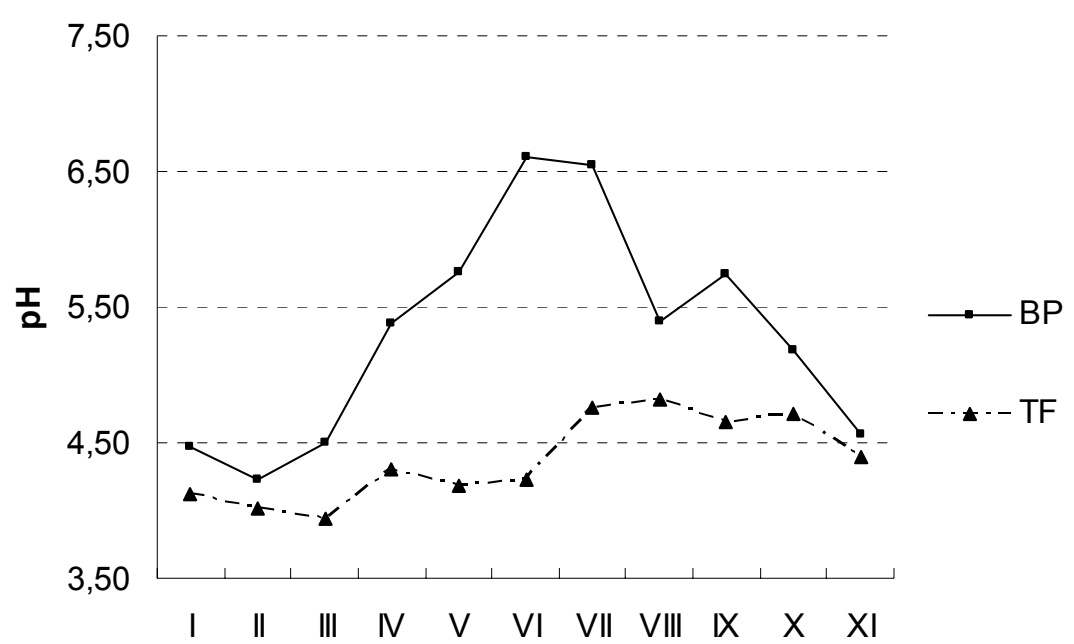

Fig. 1. Seasonal changes of $\mathrm{pH}$ in bulk precipitation (BP) and in throughfall (TF) based on mean values from the years 2004-2007

and chlorides $\left(2.12 \mathrm{mg} \cdot \mathrm{dm}^{-3}\right)$. Nitrogen forms were present in smaller concentrations: nitrate-nitrogen $-1.05 \mathrm{mg} \cdot \mathrm{dm}^{-3}$ and ammonium-nitrogen $0.83 \mathrm{mg} \cdot \mathrm{dm}^{-3}$.

Mean heavy metal concentrations in throughfall were smaller than those in bulk precipitation being equal to: $0.073 \mathrm{mg} \mathrm{Zn} \cdot \mathrm{dm}^{-3}, 0.006 \mathrm{mg} \mathrm{Pb} \cdot \mathrm{dm}^{-3}, 0.011 \mathrm{mg}$ $\mathrm{Cu} \cdot \mathrm{dm}^{-3}$, and below $0.001 \mathrm{mg} \mathrm{Cd} \cdot \mathrm{dm}^{-3}$.

\section{DISCUSSION}

\section{INTERCEPTION}

Annual mean bulk precipitation between 2004 and 2007 in Chojnów was estimated at $443 \mathrm{~mm}$ and throughfall - at $411 \mathrm{~mm}$. The difference between the two values expressed in percent was 7.2 with variation between -1 and $16 \%$. The volume of precipitation intercepted by tree crowns and evaporated later is estimated by comparing the amount of atmospheric precipitation with throughfall and stemflow. The latter was omitted in this study since it does not substantially influence the quantity of precipitation and deposition of ions to the forest floor. During a two-year long study CAPE et al. (1991) estimated losses due to interception at 13 $-37 \%$ in pine tree stand in north Britain, and showed larger differences between years than between seasons. Annual study of ten Scot pine stands in the Netherlands indicated 15\% interception (VAN EK and DRAAIJERS, 1994). Similar values (ca. 18\%) were also reported from the Canadian coniferous stands (HOULE et al., 1999) and black spruce (Picea mariana) tree stands (MORRIS et al., 2003). Conif- 
erous stands are usually characterised by higher interception than deciduous stands (OSTROWSKA et al., 1994; HOULE et al., 1999), which is understandable when one considers whole-year maintenance of assimilation apparatus and specific structure of the crowns of the former.

Difficulties in estimating interception in Chojnów associated with large differences between successive years probably resulted from adopted methodology. The volume of precipitation is calculated based on the volume of samples collected in samplers. Open collectors for snow sampling applied in winter seasons favoured losses due to evaporation. These losses may be substantial at relatively long periods of exposition, especially under strong sun exposure and positive temperatures that often occurred during last winters.

\section{PRECIPITATION CHEMISTRY, SEASONAL VARIATIONS}

Chemical composition of bulk precipitation (BP), including both wet and dry deposition is strongly modified by tree crowns. Throughfall (TF) contains substances delivered in atmospheric precipitation (in various forms) originating from solid and gas deposition and those leached from the tree foliage. It may be at the same time impoverished by sorption processes in the tree canopy.

Throughfall, on the mean annual basis, was more acidic than bulk precipitation which is in agreement with results of other studies (MORRIS et al., 2003). Similar seasonal $\mathrm{pH}$ trends, as those observed in Chojnów ( $\mathrm{pH}$ increase in summer months and decline beyond vegetation season) occurred also in pine and spruce stands in the Augustów forest (JANEK, 2002). The monthly pattern of $\mathrm{pH}$ variations observed in spruce forests in Canada was similar to that in Chojnów. $\mathrm{pH}$ decline in Canadian forests started, however, in September, thus earlier than in this study. It resulted from physiological changes in senescent needles which enhanced the excretion of organic acids (MORRIS et al., 2003).

Seasonal variations of $\mathrm{pH}$ were also observed in spruce and birch stands in Northern Czech (RŮŽIČKA, 1995). Acid precipitation in the winter season in strongly industrialised Bohemian area of Rudawy Region was explained by increased concentration of gases like sulphur dioxide and by increased deposition of protons with horizontal precipitation (e.g. frost, dew, fog). Data from air quality monitoring of the Forest Research Institute confirm an increase of sulphur oxide concentration in the region of Chojnów Forests in winter months, which may be one of the reasons for $\mathrm{pH}$ decline (WAWRZONIAK et al., 2007). Other reasons are probably typical phenological changes in the assimilation apparatus resulting in excretion of organic acids.

Total concentration of ions in precipitation expressed by electrical conductivity was generally higher in throughfall than in bulk precipitation. Similar observa- 
tions were made in tree stands growing in various geographical areas (e.g. OsTROWSKA et al., 1994; JANEK, 2002; MOSELLO et al., 2002).

Enrichment factors (WWz) are quotients of concentrations in throughfall and concentrations of the same components in bulk precipitation. These ratios are a quantitative measure summarising the interaction of tree crowns with atmospheric precipitation passing through them. Concentration of protons in analysed precipitation increased most (Tab. 2) with the average enrichment factor of 67. This phenomenon is directly related to aforementioned variations in precipitation $\mathrm{pH}$. Other ions most concentrated when passing through the canopy included $\mathrm{Mn}, \mathrm{K}, \mathrm{Al}$, and Mg which showed average annual enrichment factors of 20,9,5, and 4, respectively. Sulphate-sulphur, chloride, sodium, and calcium ions were characterised by factors between 1 and 2. In areas affected by sea aerosols, concentrations of sodium and chloride are higher in throughfall than in bulk precipitation but both ions occur in similar proportion. Geographical location of Chojnów, even though does not exclude the influence of sea aerosols, inclines to look for other sources of $\mathrm{Na}$ and $\mathrm{Cl}$.

Table 2. Enrichment factors of ion concentrations calculated for the whole year (I-XII), for summer months (IV-IX), and for winter months (X-III)

\begin{tabular}{l|r|r|r}
\hline & IV-IX & X-III & I-XII \\
\hline $\mathrm{H}^{+}$ & 125.5 & 6.9 & 67.5 \\
$\mathrm{Mn}$ & 26.6 & 12.7 & 19.6 \\
$\mathrm{~K}$ & 7.8 & 10.4 & 9.1 \\
$\mathrm{Al}$ & 8.3 & 2.1 & 5.2 \\
$\mathrm{Mg}$ & 3.2 & 5.0 & 4.1 \\
$\mathrm{Ca}$ & 1.6 & 2.2 & 1.9 \\
$\mathrm{P}^{-\mathrm{PO}_{4}{ }^{3-}}$ & 1.4 & 3.2 & 1.8 \\
$\mathrm{Cl}^{-}$ & 1.4 & 1.6 & 1.5 \\
$\mathrm{Na}^{-}$ & 1.6 & 1.4 & 1.5 \\
$\mathrm{~S}-\mathrm{SO}_{4}{ }^{2-}$ & 0.9 & 1.5 & 1.2 \\
$\mathrm{Fe}$ & 1.4 & 0.5 & 0.9 \\
$\mathrm{~N}-\mathrm{NO}_{3}{ }^{-}$ & 0.8 & 1.1 & 1.0 \\
$\mathrm{~N}-\mathrm{NH}_{4}{ }^{+}$ & 0.3 & 0.8 & 0.5 \\
$\mathrm{Cd}$ & 0.5 & 0.6 & 0.6 \\
$\mathrm{Cu}$ & 1.1 & 0.8 & 0.9 \\
$\mathrm{~Pb}$ & 2.7 & 1.1 & 2.0 \\
$\mathrm{Zn}$ & 1.3 & 0.3 & 0.8 \\
\hline
\end{tabular}

Sulphates, chlorides, and sodium, are commonly considered to behave conservatively in the tree crowns. Their increased concentrations in throughfall are hence a result of washing out dry or gaseous deposition from the canopy foliage.

Manganese (PETTY and LINDBERG, 1990), as well as potassium, magnesium, and calcium (OSTROWSKA et al., 1994; HOULE et al., 1999; MOSELlO et al., 2002) 
are subject to substantial leaching from tree crowns. Calcium shows usually the release pattern similar to potassium and magnesium (HOULE et al., 1999; MOSELLO et al., 2002). Enhancement of $\mathrm{K}$ and $\mathrm{Mg}$ was ca. 2-3 times larger than that of $\mathrm{Ca}$ in precipitations in Chojnów. Moreover, no significant linear correlations were observed between $\mathrm{Ca}$ and $\mathrm{Mg}$ in throughfall (Tab. 3). Significant correlations were found, however, between the concentration of acidifying ions $\left(\mathrm{Cl}, \mathrm{NO}_{3}, \mathrm{SO}_{4}\right)$ and $\mathrm{Ca}$; but not $\mathrm{K}$ and $\mathrm{Mg}$. Concentrations of calcium, magnesium, and acidifying chlorides, nitrogen, and sulphates in throughfall and in bulk precipitation were significantly correlated but those of potassium were not (Tab. 4). These relationships (or their lack) may allow for concluding that calcium in throughfall is controlled by different mechanisms than potassium.

Analysis of trends in enrichment factors throughout the year, based on averaged four-year data (Fig. 2) showed that $\mathrm{Mg}, \mathrm{K}$, and to some degree $\mathrm{Cl}$ presented a similar seasonal dynamics with the enrichment maximum in October associated with ageing of assimilation apparatus. Also, in the period of an intensive growth and blooming (May and June) the release of these elements was more intensive. Calcium for most of vegetation season followed the pattern characteristic for magnesium though the peak of maximum enrichment was noted in November and December.

$\mathrm{Ca}, \mathrm{K}, \mathrm{Cl}$, and $\mathrm{SO}_{4}$ in throughfall in the Norwegian forests were present in lower concentrations in summer months and higher in the beginning and at the end of vegetation season. Seasonal variation of $\mathrm{Ca}$ and $\mathrm{K}$ in throughfall was attributed to the enrichment of precipitation when it was passing through the trees crowns. Moreover, it was not excluded that cations were washed out from the surface of needles or were leaching from the needles falling to containers in fall (MOFFAT et al., 2002), or in winter with snow (HoUle et al., 1999). Laboratory experiments showed that pine pollen increased the concentration of sulphate and potassium but not of magnesium and calcium. The influence of pollens in field conditions was considered negligibly small. Releasing of ions from tree crowns was enhanced by heat and pathogen infections (VAN EK and DRAAIJERS, 1994; PEDERSEN et al., 1995). Aphid attacks increased the release of soluble organic carbon compounds from spruce needles (STADLER and MICHALZIK, 1998). The release of K, Mg and Ca cations was associated with the loss of organic carbon from the interior of assimilation apparatus (HOULE et al., 1999).

Nitrate-nitrogen was not enriched in tree stand in Chojnów (enrichment factor $=1$ ) and ammonium ions was uptaken by tree crowns (annual mean enrichment factor $=0.5$ ). Similar results for $\mathrm{NH}_{4}$ were obtained in pine stand in the Augustów forest while the concentration of $\mathrm{NO}_{3}$ in throughfall from this stand increased (JANEK, 2002). Other studies showed higher concentrations of inorganic nitrogen in the bulk precipitation (MOSELLO et al., 2002; MORRIS et al., 2003) or under canopies (STEVENS and NORRIS, 1994). The decline of inorganic nitrogen forms in throughfall is caused by uptake of these compounds by needles but biological ac- 


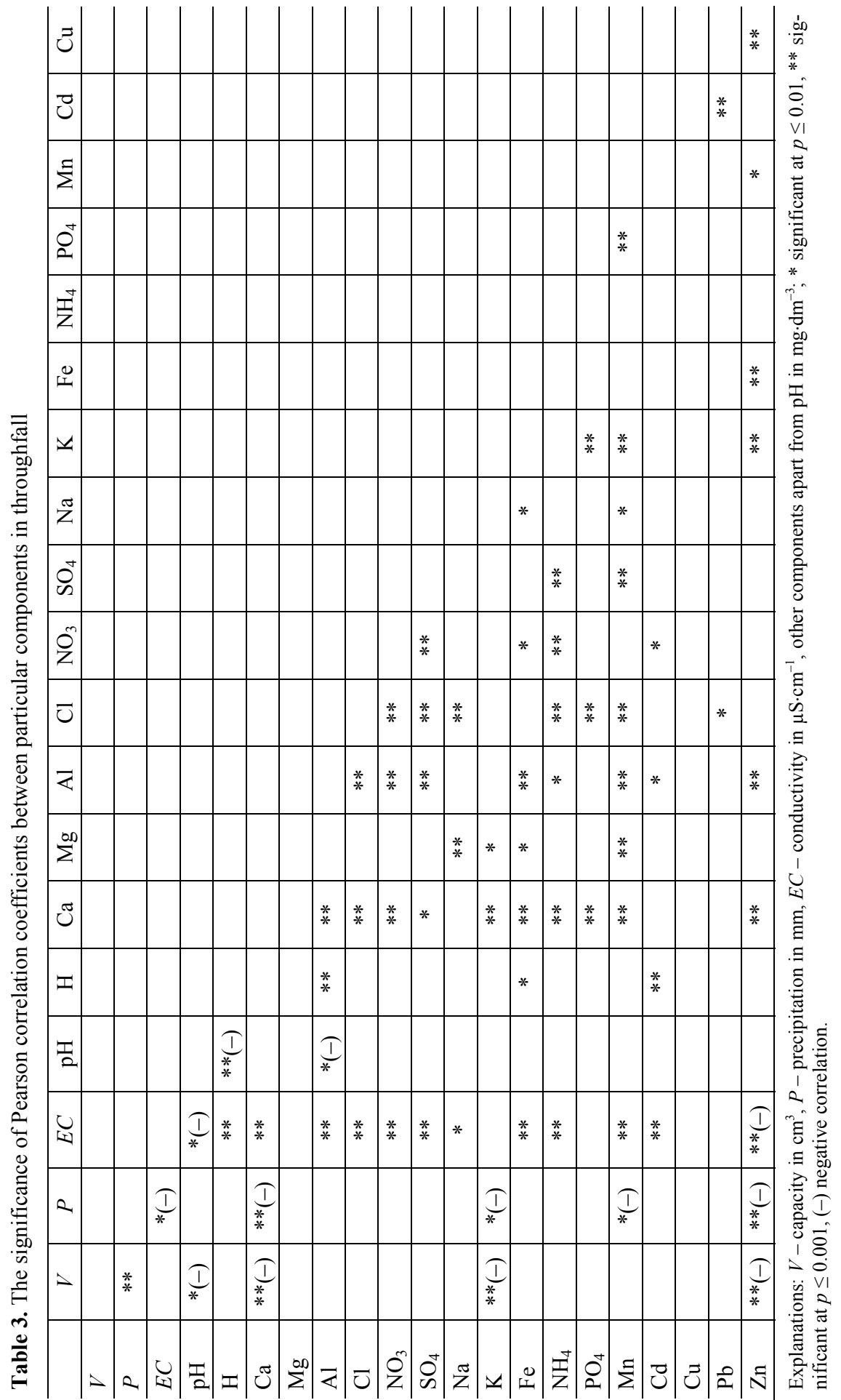




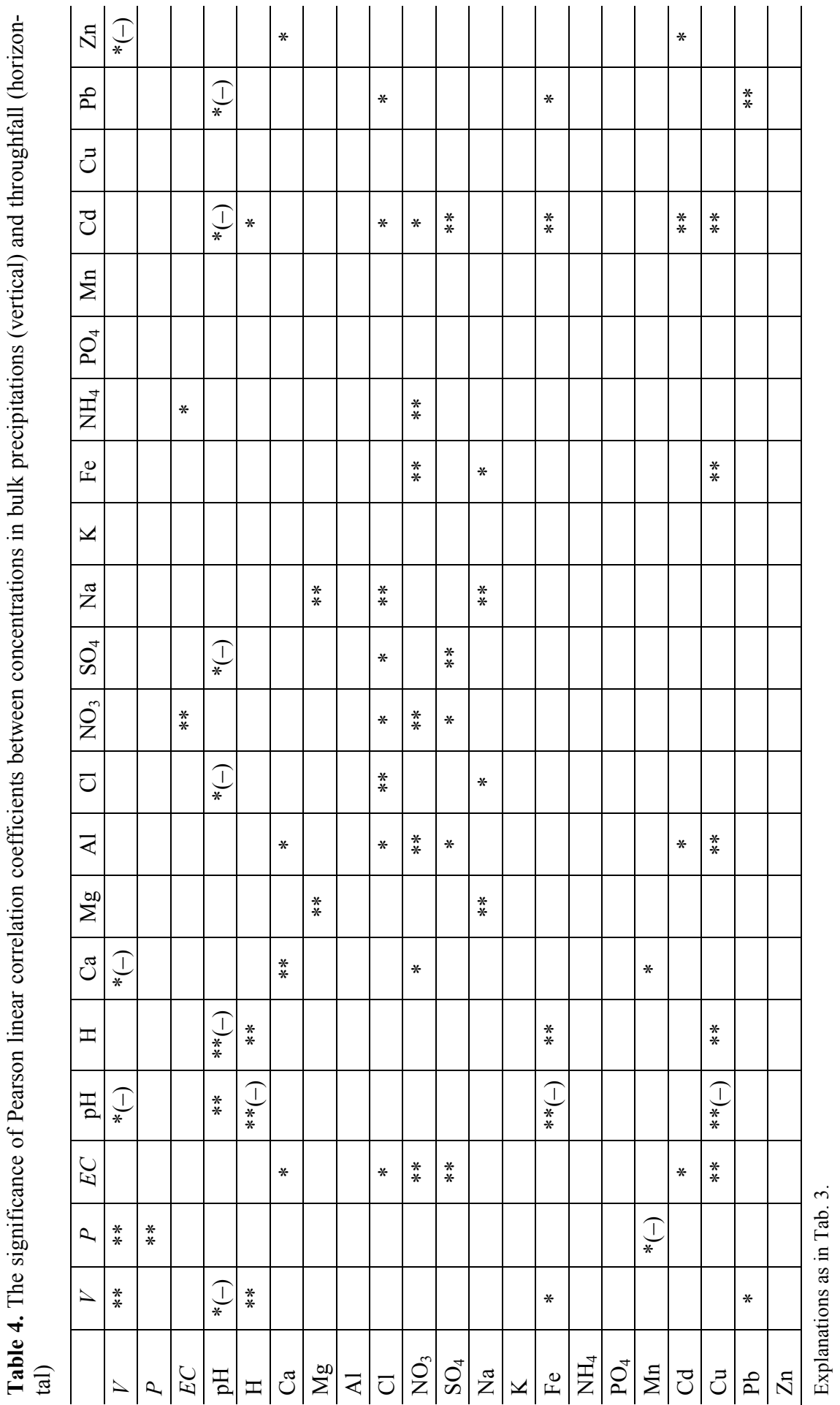



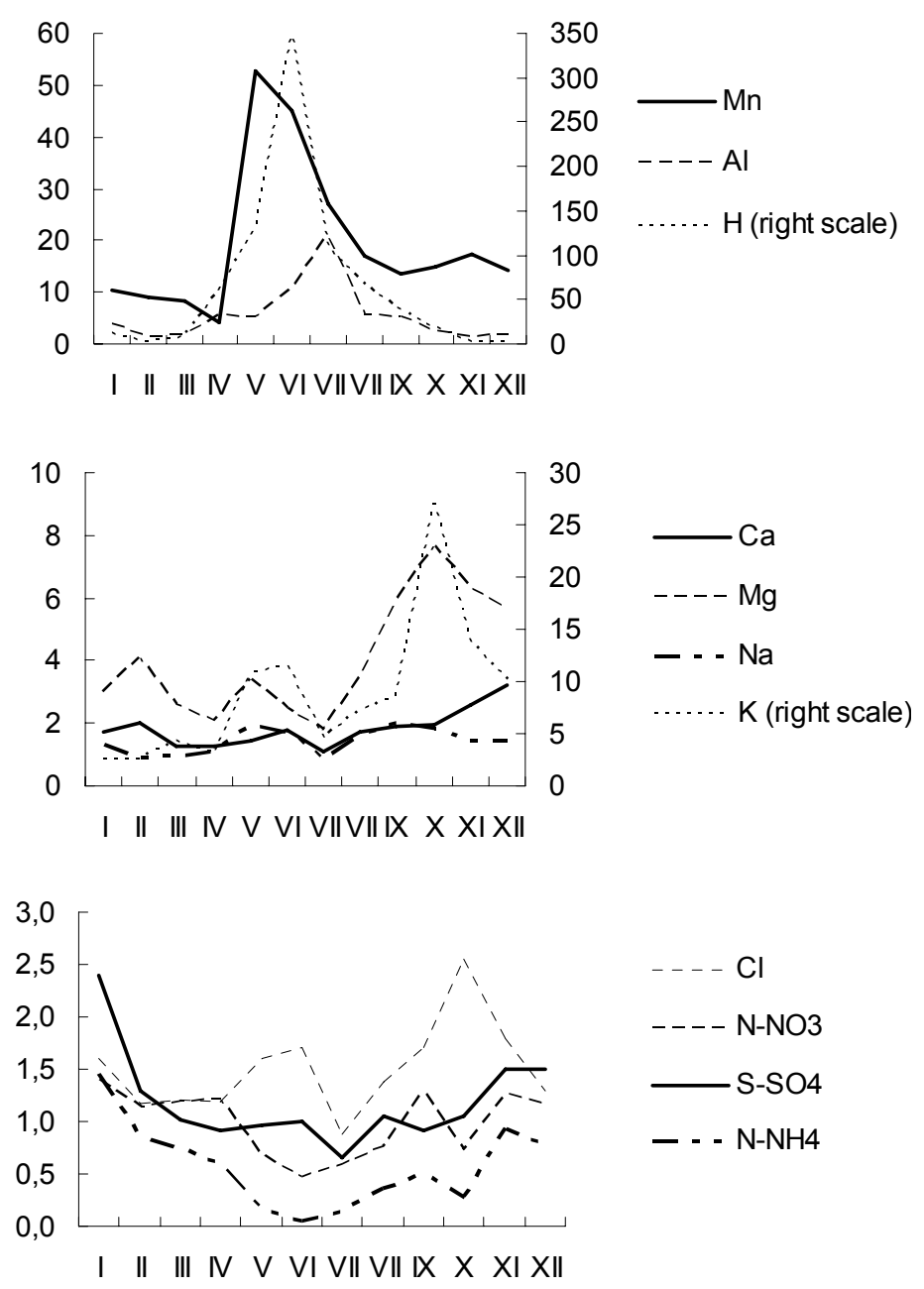

Fig. 2. Seasonal changes of ionic enrichment factors based on 4-year study

tivity of epiphytic lichens in trees crowns should also be taken into account (HOULE et al., 1999).

Organic nitrogen contributed more to the total nitrogen concentrations in throughfall as compared with bulk precipitation (BLEW et al., 1993; MOSELLO et al., 2002). This form of nitrogen was not, however, considered in water chemistry analyses in Chojnów. Its concentration is higher in the vegetation period - undoubtedly contributing significantly to nitrogen cycling (MORRIS et al., 2003).

Enrichment ratios of $\mathrm{Cd}, \mathrm{Zn}$ and $\mathrm{Cu}$ reached annual means between 0.6 and 0.9; respective value for $\mathrm{Pb}$ was 2 . These results agree with published data on small uptake of $\mathrm{Zn}$ by tree crowns and leaching of Pb (PETTY and LindBERG, 1990). Results of heavy metals determination should be treated with caution. Concentrations 
of heavy metals in precipitation were often close to the detection limit of adopted analytical method and concomitant uncertainty was relatively high.

\section{CONCLUSIONS}

Examination of chemical composition of precipitation waters in Chojnów indicated that throughfall of the pine stand were more acid than bulk precipitation. At the same time throughfall was characterised by higher electrical conductivity and higher concentration of many examined ions. Atmospheric precipitations passing through tree crowns were enriched in protons and in $\mathrm{Mn}, \mathrm{K}, \mathrm{Al}, \mathrm{Mg}$, and $\mathrm{Ca}$ ions (mean enrichment factors for the study period were 67, 20, 9, 5, 4 and 2, respectively). Ammonium-nitrogen was substantially intercepted by tree crowns whereas nitrates occurred in both types of precipitations in similar concentrations. Differences in enrichment factors among particular months reflected the intensity of processes operating in trees crowns, resulting from both natural and anthropogenic reasons, e.g. from increased emission of sulphur compounds in the winter periods.

\section{REFERENCES}

1. Blew R.D., Iredale D.R., Parkinson D., 1993. Throughfall nitrogen in white spruce forest in southwest Alberta, Canada. Can. J. Forest Res., 23, 11: 2389-2394.

2. CAPE J.N., BROWn A.H.F., RoBertSON S.M.C., HowsOn G., PATERSON I.S., 1991. Interspecies comparison of throughfall and stemflow at three sites in northern Britain. Forest Ecol. Manag., 46: 165-177 .

3. HANSEN K., 1994. In-canopy throughfall measurements: P. II. Canopy inter-actions and dry deposition. In: Throughfall and canopy interactions in spruce forest. Ed. K. Hansen. Lyngby, Denmark, Forskningsserien, 8: 41-57.

4. Houle D., Ouimet R., Paquin R., Laflamme J.-G., 1999. Interactions of atmospheric deposition with a mixed hardwood and a coniferous forest canopy at the Lake Clair Watershed (Duchesnay, Quebec). Can. J. Forest Res., 29: 1944-1957.

5. JANEK M., 2002. Wpływ drzewostanów iglastych na jakość wód opadowych. Cz. II. Sezonowe zróżnicowanie wielkości i chemizmu opadów w drzewostanach iglastych Puszczy Augustowskiej. Pr. Inst. Bad. Leśn. Ser. A, 2(934): 73-86.

6. KRZYSZTOFiAK L., 2006. Stacja Bazowa Wigry. W: Stan, przemiany i funkcjonowanie geoekosystemów Polski w latach 1994-2004 na podstawie Zintegrowanego Monitoringu Środowiska Przyrodniczego. Red. A. Kostrzewski, R. Kruszyk. Bibl. Monitor. Środ., Warszawa, IOŚ: 57-92.

7. KvaAlen H., Solberg S., Clarke N., Torp T., Aamlid D., 2002. Time series study of concentrations of $\mathrm{SO}_{4}^{2-}$ and $\mathrm{H}^{+}$in precipitation and soil waters in Norway. Env. Pollut., 117: 215-224.

8. Manual on methods and criteria for harmonized sampling, assessment, monitoring and analysis of the effects of air pollution on forests (http://www.icp-forests.org/Manual.htm)

9. Moffat A.J., KvaAlen H., Solberg S., Clarke N., 2002. Temporal trends in throughfall and soil water chemistry at three Norwegian forests, 1986-1997. Forest Ecol. Manag., 168: 15-28.

10. MorRIs D.M., GORDON A.G., GORDON A.M., 2003. Patterns of canopy interception and throughfall along a topographic sequence for black spruce dominated forest ecosystems in northwestern Ontario. Can. J. Forest Res., 33: 1046-1060. 
11. Mosello R., Brizzio M.C., Kotzias D., Marchetto A., Rembges D., Tartari G., 2002. The chemistry of atmospheric deposition in Italy in the framework of the National Programme for Forest Ecosystems Control (CONECOFOR). J. Limnol., 61 (Suppl. 1): 77-92.

12. Ocena stanu środowiska i procesów zachodzących w lasach zlewni potoku Ratanica (Pogórze Wielickie, Polska Południowa), 1996. Pr. zbior. Red. K. Grodzińska, R. Laskowski. Warszawa, PIOŚ: 139.

13. Ostrowska A., Gawliński S., SienKiewicz J., PoręBSKa G., 1994. Ocena chemizmu wód opadowych, powierzchniowych i glebowych na tle badań w Stacji Kompleksowego Monitoringu Puszcza Borecka. Warszawa, PIOŚ: 80.

14. Pedersen L.B., Hansen K., Bille-Hansen J., Løber M., Hovmand M.F., 1995. Throughfall and canopy buffering in three sitka spruce stands in Denmark. Water Air Soil Pollut., 85: 1593-1598.

15. PetTy W.H., LindBerg S.E., 1990. An intensive 1-month investigation of trace metal deposition and throughfall at a mountain spruce forest. Water Air Soil Pollut., 53: 213-226.

16. RŮŽIČKA Š., 1995. Throughfall quality and quantity in polluted and damaged ecosystems in northern Bohemia. Water Air Soil Pollut., 83: 205-218.

17. Stadler B., MichalziK B., 1998. Aphid infested Norway spruce are "hot spots" in throughfall carbon chemistry in coniferous forests. Can. J. Forest Res., 28: 1717-1722.

18. StEVENS P.A., NORRIS D.A., 1994. The impacts of atmospheric $\mathrm{N}$ inputs on throughfall, soil and stream water interactions for different aged forest and moorland catchments in Wales. Water Air Soil Pollut., 73: 297-317.

19. SzPikowski J., Domańska M., Kruszyk R., SzPikowska G., TYlkowski J., 2006. Stacja Bazowa Storkowo. W: Stan, przemiany i funkcjonowanie geoekosystemów Polski w latach 1994-2004 na podstawie Zintegrowanego Monitoringu Środowiska Przyrodniczego. Red. A. Kostrzewski, R. Kruszyk. Bibl. Monitor. Środ. Warszawa, IOŚ: 93-136.

20. ULRICH B., 1983. Interaction of forest canopies with atmospheric constituents: $\mathrm{SO}_{2}$, alkali and earth alkali cations and chloride. In: Effects of accumulation of air pollutants in forest ecosystems. Eds. B. Ulrich, J. Pankrath. D. Reidel Publ.: 33-45.

21. VAN EK R., DRAAIJERS G.P.J., 1994. Estimates of atmospheric deposition and canopy exchange for three common tree species in the Netherlands. Water Air Soil Pollut., 73: 61-82.

22. Wawrzoniak J., Dobrowolski M., Kluziński L., Kowalska A., Lech P., MaŁachowska J., SzCZYGIEŁ R., UBYSZ B., ŚLUSARSKi S., 2007. Stan uszkodzenia lasów w Polsce w 2006 roku na podstawie badań monitoringowych. Sękocin Stary, IBL: 94.

\section{STRESZCZENIE}

\section{Jakość wód opadowych w środowisku leśnym na stałej powierzchni obserwacyjnej w Nadleśnictwie Chojnów w latach 2004-2007}

Słowa kluczowe: opady atmosferyczne, opady na otwartej przestrzeni, opady podkoronowe, wskaźniki wzbogacania

Badania wód opadowych w środowisku leśnym prowadzono w latach 20042007 na stałej powierzchni obserwacyjnej, założonej w drzewostanie sosnowym na siedlisku bór mieszany świeży w Nadleśnictwie Chojnów. Badania te dotyczyły m.in. ilości i składu chemicznego opadów atmosferycznych na otwartej przestrzeni oraz pod okapem drzewostanu. W próbkach oznaczano $\mathrm{pH}$ i przewodność elek- 
tryczną właściwą oraz wykonywano analizy zawartości jonów: $\mathrm{Ca}, \mathrm{Mg}, \mathrm{Cl}, \mathrm{NO}_{3}$, $\mathrm{SO}_{4}, \mathrm{Na}, \mathrm{K}, \mathrm{Fe}, \mathrm{Mn}, \mathrm{Al}, \mathrm{NH}_{4}, \mathrm{PO}_{4}, \mathrm{Zn}, \mathrm{Cd}, \mathrm{Cu}$ i Pb.

Wielkość opadu rocznego na otwartej przestrzeni w latach 2004-2007 wyniosła średnio $443 \mathrm{~mm}$. Średnie ważone pH (ważone objętością) w tym okresie wyniosło 4,8 , zaś przewodność elektryczna właściwa wyniosła $47 \mu \mathrm{S} \cdot \mathrm{cm}^{-1}$. Średni opad pod koronami drzew był mniejszy niż na otwartej przestrzeni $\left(411 \mathrm{~mm} \cdot \mathrm{rok}^{-1}\right)$. Jednocześnie opady podkoronowe charakteryzowała niższa wartość pH (średnia 4,2) oraz większa przewodność (średnio $62 \mu \mathrm{S} \cdot \mathrm{cm}^{-1}$ ). Opady przechodząc przez korony drzew ulegały wzbogaceniu - w największym stopniu w protony, jony $\mathrm{Mn}, \mathrm{K}, \mathrm{Al}$, Mg i Ca (wskaźniki wzbogacenia stężenia średnio w badanym okresie wyniosły odpowiednio: $67,20,9,5,4$ i 2).

Reviewers:

Dr. Ludmita Rossa

Dr. Józef Wójcik 